\title{
PD-L1 Expression Induced by the 2009 Pandemic Influenza A(H1N1) Virus Impairs the Human T Cell Response
}

\author{
Nuriban Valero-Pacheco, ${ }^{1,2}$ Lourdes Arriaga-Pizano, ${ }^{1}$ Eduardo Ferat-Osorio, ${ }^{1}$ \\ Luz María Mora-Velandia, ${ }^{1}$ Rodolfo Pastelin-Palacios, ${ }^{3}$ Miguel Ángel Villasís-Keever, \\ Celia Alpuche-Aranda, ${ }^{5}$ Luvia Enid Sánchez-Torres, ${ }^{2}$ Armando Isibasi, ${ }^{1}$ \\ Laura Bonifaz, ${ }^{1}$ and Constantino López-Macías ${ }^{1}$ \\ ${ }^{1}$ Medical Research Unit on Immunochemistry (UIMIQ), Specialties Hospital, National Medical Centre "Siglo XXI," \\ Mexican Social Security Institute (IMSS), 06720 México, DF, Mexico \\ ${ }^{2}$ Departamento de Inmunología, Escuela Nacional de Ciencias Biológicas, Instituto Politécnico Nacional, 11340 México, DF, Mexico \\ ${ }^{3}$ Facultad de Química, Universidad Nacional Autónoma de México, 04510 México, DF, Mexico \\ ${ }^{4}$ Unidad de Investigación en Epidemiología Clínica, Hospital de Pediatría, Centro Médico Nacional Siglo XXI, \\ Instituto Mexicano del Seguro Social (IMSS), 06720 México, DF, Mexico \\ ${ }^{5}$ Instituto Nacional de Salud Pública, 62100 Cuernavaca, MOR, Mexico
}

Correspondence should be addressed to Laura Bonifaz; labonifaz@yahoo.com and Constantino López-Macías; constantino@sminmunologia.org

Received 8 July 2013; Accepted 22 August 2013

Academic Editor: Oscar Bottasso

Copyright (c) 2013 Nuriban Valero-Pacheco et al. This is an open access article distributed under the Creative Commons Attribution License, which permits unrestricted use, distribution, and reproduction in any medium, provided the original work is properly cited.

PD-L1 expression plays a critical role in the impairment of T cell responses during chronic infections; however, the expression of PD$\mathrm{L} 1$ on T cells during acute viral infections, particularly during the pandemic influenza virus (A(H1N1)pdm09), and its effects on the $\mathrm{T}$ cell response have not been widely explored. We found that $\mathrm{A}(\mathrm{H} 1 \mathrm{~N} 1) \mathrm{pdm} 09$ virus induced $\mathrm{PD}-\mathrm{L} 1$ expression on human dendritic cells (DCs) and T cells, as well as PD-1 expression on T cells. PD-L1 expression impaired the T cell response against A(H1N1)pdm09 by promoting $\mathrm{CD}^{+} \mathrm{T}$ cell death and reducing cytokine production. Furthermore, we found increased PD-L1 expression on DCs and $\mathrm{T}$ cells from influenza-infected patients from the first and second 2009 pandemic waves in Mexico City. PD-L1 expression on $\mathrm{CD}^{+} \mathrm{T}$ cells correlated inversely with $\mathrm{T}$ cell proportions in patients infected with $\mathrm{A}(\mathrm{H} 1 \mathrm{N1} 1) \mathrm{pdm} 09$. Therefore, PD-L1 expression on DCs and T cells could be associated with an impaired T cell response during acute infection with A(H1N1)pdm09 virus.

\section{Introduction}

Programmed death-ligand 1 (PD-L1, B7-H1, CD274) is a coinhibitory molecule that has been associated with impairment of the T cell response. PD-L1 is one of the ligands that interact with the inhibitory PD-1 receptor, which is expressed on activated T cells [1]. PD-L1 expression is induced in a variety of human cells and tissues, including $\mathrm{T}$ cells and dendritic cells (DCs) [2]. PD-1/PD-L1 signaling interferes with the $\mathrm{T}$ cell response by blocking the CD28-mediated pathway, thereby affecting the expression of antiapoptotic genes, cell cycle progression [3], and cytokine production [4]. The role of the PD-1/PD-L1 signaling pathway in chronic infections, such as HIV or HCV infection, has been widely explored [5]. PD$\mathrm{L} 1$ signaling is involved in the induction of $\mathrm{T}$ cell exhaustion, which impairs the response against pathogens. Additionally, this pathway is important in regulating the balance between an effective antimicrobial response and tissue damage [5]. The role of PD-1/PD-L1 during acute infections has been studied in mouse models of rabies [6], influenza [7], sepsis [8], RSV, and HMPV, and in patients with septic shock [9] with divergent findings, most of which suggest an inhibitory role for PD-L1. Recently, the expression of PD-1 and PDL1 in the lungs of patients infected with the 2009 pandemic influenza $\mathrm{A}(\mathrm{H} 1 \mathrm{~N} 1)$ virus $(\mathrm{A}(\mathrm{H} 1 \mathrm{~N} 1) \mathrm{pdm} 09)$ was documented [10]. During chronic viral infections, PD-L1 expression on 
$\mathrm{T}$ cells has been reported to be crucial in the impairment of the T cell response $[5,11]$. However, PD-L1 expression on DCs and $\mathrm{T}$ cells during acute viral infections, particularly during $\mathrm{A}(\mathrm{H} 1 \mathrm{N1}) \mathrm{pdm} 09$ infection, has not been widely studied.

Influenza virus infection may trigger an exacerbated immune response, which has been correlated with illness severity and sometimes death [12-14]. Lymphopenia is a clinical feature of influenza infections caused by seasonal influenza [15], avian $\mathrm{H} 5 \mathrm{~N} 1$ [16], and $\mathrm{A}(\mathrm{H} 1 \mathrm{~N} 1) \mathrm{pdm} 09$ viruses [17]. With regard to the cellular immune response, leukocytes exposed to seasonal influenza virus have been shown to proliferate in response to the virus, but did not show a subsequent response to mitogen stimulation [18]. Additionally, influenza virus can induce apoptosis of several cell types, including peripheral blood-derived macrophages [19], avian cell lines [20], and T cells from healthy subjects [21].

Cellular immunity, may contribute to virus clearance, reduction of symptoms and prevention of secondary infections $[22,23]$. The $\mathrm{CD} 4^{+} \mathrm{T}$ cell-mediated immune response against influenza plays a role in limiting the severity of infection in the absence of previous antibodies [24]. However, during the acute phase of infection, $T$ cells from patients infected with $\mathrm{A}(\mathrm{H} 1 \mathrm{N1}) \mathrm{pdm} 09$ cannot differentiate into effector cells, highly express the death receptor CD95 (Fas), and do not respond to mitogens; nevertheless, $\mathrm{T}$ cell function is restored during the convalescent phase [25]. Therefore, the lymphopenia and $\mathrm{T}$ cell dysfunction reported in the $\mathrm{A}(\mathrm{H} 1 \mathrm{~N} 1) \mathrm{pdm} 09$ infection might be induced by PD-L1 expressed on T cells, which could have affected $\mathrm{T}$ cell function through a mechanism similar to that which has been reported in chronic viral infections. This study evaluated the expression of PD-L1 on DCs and T cells and its effects on T cell response, as well as its possible implications during $\mathrm{A}(\mathrm{H} 1 \mathrm{~N} 1) \mathrm{pdm} 09$ infection at the beginning of the 2009 pandemic outbreak at its epicenter.

\section{Materials and Methods}

2.1. Patients and Healthy Controls. Thirteen patients from two hospitals from the Mexican Social Security Institute (IMSS) with RT-PCR-confirmed pandemic influenza infection (pH1N1+), 12 PCR negative patients with influenza-like illness (ILI) (pH1N1-), and 10 healthy controls (HC) were included in this report. Patients were recruited during the first and second pandemic waves in Mexico City. Informed consent was obtained from participants. Study approval was obtained from the IMSS through the National Commission of Scientific Research, which comprises the Scientific, Ethics, and Biosafety Committees, in accordance with Good Clinical Practice. The project's ethics authorization number is: CNIC 2010-785-002.

2.2. Blood Samples and PBMC Separation. Blood samples from patients and controls were collected in EDTA tubes. Peripheral blood mononuclear cells (PBMCs) were separated by gradient centrifugation using Lymphoprep (Axis-Shield, Oslo, Norway) and cryopreserved until use. PBMCs from buffy coats were obtained from healthy volunteer donors according to institutional guidelines.
2.3. PBMC Stimulation. PBMCs $\left(1 \times 10^{6}\right)$ from buffy coats were placed in 24-well plates (Corning Inc., Corning, NY, USA) with RPMI-1640 (supplemented with HEPES, 10\% heat-inactivated fetal bovine serum, $2 \mathrm{mM}$ L-glutamine, $100 \mathrm{UmL}^{-1}$ penicillin, and $100 \mu \mathrm{gmL}^{-1}$ streptomycin, all from Gibco, Life Technologies, Carlsbad, CA, USA). They were stimulated with $10 \mathrm{pgmL}^{-1}$ staphylococcal enterotoxin B (SEB, Toxin Technology, Sarasota, FL, USA), $10 \mu \mathrm{gmL}^{-1}$ of the TLR7 synthetic agonist CL264 (Invivogen, San Diego, $\mathrm{CA}, \mathrm{USA}$ ), $80 \mathrm{HAUmL}^{-1}$ (hemagglutination units) of live and UV-inactivated influenza A/Mexico/4482/2009(H1N1) virus and A/Panama/2007/1999(H3N2) virus provided by the Instituto Nacional de Referencia Epidemiológica (INDRE), or $10 \mu \mathrm{gmL}^{-1}$ of recombinant $\mathrm{A}(\mathrm{H} 1 \mathrm{N1}) \mathrm{pdm} 09$ virus hemagglutinin (HA), kindly provided by Dr. Clara Espitia from the Instituto de Investigaciones Biomédicas, UNAM. The PBMCs were incubated for $18 \mathrm{~h}, 3$ or 7 days at $37^{\circ} \mathrm{C} / 5 \% \mathrm{CO}_{2}$ prior to flow cytometry analysis of PD-1 and PD-L1 expression on DCs and T cells, respectively. For de novo protein synthesis analysis, PBMCs were stimulated with $\mathrm{A}(\mathrm{H} 1 \mathrm{N1}) \mathrm{pdm} 09$ for $2 \mathrm{~h}$, then cycloheximide $\left(\mathrm{CHX}, 50 \mu \mathrm{gmL}^{-1}\right)$ was added to the culture for another $16 \mathrm{~h}$.

2.4. T Cell and Dendritic Cell Enrichment and Culture. PBMCs $\left(2 \times 10^{7}\right)$ from buffy coats were incubated in supplemented RPMI-1640 at $37^{\circ} \mathrm{C} / 5 \% \mathrm{CO}_{2}$ for $1.5 \mathrm{~h}$, in Petri dishes (Fisher Scientific, Pittsburgh, PA, USA). Nonadherent cells were removed, washed, and quantified. T cells were then isolated by negative selection using a cocktail of PE-conjugated anti-CD19, anti-CD14 (eBioscience, San Diego, CA), antiCD56, and anti-HLA-DR antibodies (BD Biosciences, San Jose, CA), with anti-PE magnetic microbeads in a MidiMACS system with LD columns (Miltenyi Biotec, Auburn, CA, USA). Dendritic cells were isolated the same way, but instead of anti-HLA-DR, PE-conjugated anti-CD3 (eBioscience) was used.

2.5. Stimulation of Enriched T Cells and DCs. The enriched $\mathrm{T}$ cells $\left(5 \times 10^{5}\right.$ cells/well $)$ were placed into 48 -well plates (Corning) with supplemented RPMI-1640 and stimulated with $10 \mathrm{pgmL}^{-1} \mathrm{SEB}$ and $80 \mathrm{HAU} / \mathrm{mL} \mathrm{A}(\mathrm{H} 1 \mathrm{N1}) \mathrm{pdm} 09$ virus and incubated for $48 \mathrm{~h}$ at $37^{\circ} \mathrm{C} / 5 \% \mathrm{CO}_{2}$. Enriched DCs $\left(1.5 \times 10^{6}\right)$ were placed in 24 -well plates (Corning) with supplemented RPMI-1640 and stimulated with CL264 or $\mathrm{A}(\mathrm{H} 1 \mathrm{~N} 1) \mathrm{pdm} 09$ virus. The cells were incubated for $18 \mathrm{~h}$ at $37^{\circ} \mathrm{C} / 5 \% \mathrm{CO}_{2}$, collected, and labeled for flow cytometric analysis.

2.6. T Cell Proliferation and Cell Death. Buffy coat PBMCs $\left(5 \times 10^{6}\right.$ cells/well $)$ were left untreated or stimulated with influenza virus and incubated for $18 \mathrm{~h}$. Next, the cells were labeled with CFSE (Invitrogen Life Technologies, Carlsbad, CA, USA), and $5 \times 10^{5}$ cells/well were seeded into plates. These cells were left untreated or treated with $25 \mu \mathrm{gmL}^{-1}$ antiPD-L1 antibody 29E.2A3 (BioLegend, San Diego, CA, USA) or an isotype control MPC-11 (BioLegend) on days 0,3 , and 5 , or with SEB $\left(10 \mathrm{pgmL}^{-1}\right)$ on day 0 . The cells were incubated 
for 7 days at $37^{\circ} \mathrm{C} / 5 \% \mathrm{CO}_{2}$, collected, and proliferation was measured by flow cytometry. The proportion of apoptotic cells was detected by flow cytometry with Annexin V/Pacific Blue and 7-AAD staining (both from BioLegend).

2.7. Cytokine Production. Supernatants from the T cell proliferation culture were cryopreserved until use. Cytokine levels were measured using the human Th1/Th2/Th17 cytometric bead array kit (CBA) according to the manufacturer's instructions (BD Biosciences).

2.8. Sorting of $c D C$ s and Isolation of $\mathrm{CD}^{+}$Memory $\mathrm{T}$ Cells. Sorting of cDCs from enriched DCs was performed in a FACSAria cell sorter (BD Biosciences). After the preenrichment previously described, the negative cell fraction was labeled with anti-CD123-/PE-Cy5 and anti-HLA-DR/APC$\mathrm{Cy} 7$ (BioLegend), to identify the CDC population; this population was isolated with a purity of about $90 \%$. Memory CD $4^{+}$ $\mathrm{T}$ cells $\left(\mathrm{T}_{\mathrm{m}}\right)$ were isolated with the human memory $\mathrm{CD} 4^{+} \mathrm{T}$ cell isolation kit (Miltenyi Biotec). For co-culture assays, a 1:3 ratio of cDCs: T cells $\left(1.5 \times 10^{4} \mathrm{cDCs}\right.$ and $4.5 \times 10^{4} \mathrm{~T}$ cells $)$ were placed in 96 -well plates with $\mathrm{A}(\mathrm{H} 1 \mathrm{~N} 1) \mathrm{pdm} 09$ virus and incubated for 7 days at $37^{\circ} \mathrm{C} / 5 \% \mathrm{CO}_{2}$, with or without PDL1 blocking; the supernatant was collected to conduct CBA's analysis. Representative plots of $\mathrm{cDCs}$ and $\mathrm{CD} 4^{+} \mathrm{T}$ cell purity are shown in Figure S1 (see Supplementary Material available online at http://dx.doi.org/10.1155/2013/989673).

2.9. Flow Cytometric Analysis. The cryopreserved PBMCs from patients and controls were thawed and counted. Only the samples with total PBMCs above $1 \times 10^{6}$ cells were evaluated for PD-L1 expression on both DCs and T cells. When the number of cells was inferior, only DCs or T cells were analyzed. Hence, PD-L1 expression was analyzed on T cells of 9/13 pH1N1+ patients and 6/12 pH1N1- patients. In the case of DCs, PD-L1 expression was evaluated in 11/13 pH1N1+ patients and 10/12 in the pH1N1- group. The PBMCs from patients were labeled with the fluorochrome-conjugated antibodies, PD-L1/PE-Cy7, CD8/APC-Cy7, HLA-DR/APC$\mathrm{H} 7, \mathrm{CD} 4 / \mathrm{PE}-\mathrm{Cy} 7, \mathrm{CD} 123 / \mathrm{PE}-\mathrm{Cy} 5$, and the lineage cocktail (Lin, CD3/PE, CD14/PE, CD56/PE, and CD19/PE) (BD Biosciences) and fixed with paraformaldehyde (4\%). The T cells and DCs from buffy coats used for in vitro PD-L1 expression, proliferation, and cell death assays were labeled with all of the former antibodies, in addition to PD-1/FITC, CD4/APC$\mathrm{Cy} 7, \mathrm{CD} 2 / \mathrm{PE}$, (BD Biosciences), and CD8/APC (Invitrogen). The cells were fixed with FACS Lysing Solution 1x (BD Biosciences) and cell viability was determined with Hoechst 33258 staining (Invitrogen). All samples were analyzed in either a FACSAria II or a FACSCanto II (BD Biosciences) using FlowJo (version 8.7) software (Tree Star Inc., Ashland, OR, USA). A minimum of $1 \times 10^{4} \mathrm{CD}^{+}$events were collected for $\mathrm{T}$ cell samples and $5 \times 10^{4}$ Lin-events for DCs samples.

2.10. Statistical Analysis. Statistics were calculated with Prism, version 5.0, from GraphPad Software (San Diego, CA, USA). To test for significant differences in PD-L1 expression between treatments, MFI values were normalized and a parametric Student's $t$-test with a two-tailed $P$ value was performed. In the case of patients, a nonparametric Student's $t$-test was performed (Mann-Whitney test). Correlations were established with Spearman's test. Statistical significance was established at $P<0.05$.

\section{Results}

3.1. PD-L1 Is Expressed on Human Dendritic Cells and T Cells, Whereas PD-1 Is Only Expressed on T Cells after Exposure to A(H1N1)pdm09 Virus. To test whether A(H1N1)pdm09 could induce PD-L1 and PD-1 expression on DCs and T cells, we stimulated human PBMCs with A(H1N1)pdm09. After $18 \mathrm{~h}$ of contact with the virus, we detected PD-L1 expression on conventional $(\mathrm{cDCs})(P<0.01)$ and plasmacytoid dendritic cells (pDCs) $(P<0.001)$ (Figure 1(a)). This was similar to the expression induced by the synthetic TLR7 agonist CL264. The $\mathrm{A}(\mathrm{H} 1 \mathrm{N1}) \mathrm{pdm} 09$ virus induced $\mathrm{PD}-\mathrm{L} 1$ on both $\mathrm{CD}^{+}(P<0.001)$ and $\mathrm{CD} 8^{+}$T cells $(P<0.001)$ similar to SEB (Figure 1(a)). We did not observe H3N2 seasonal virus induction of PD-L1 expression on any of the analyzed cells. In addition, after stimulation for $18 \mathrm{~h}$ with $\mathrm{A}(\mathrm{H} 1 \mathrm{~N} 1) \mathrm{pdm} 09$ virus, we detected no PD-1 expression on DCs or T cells (Figure S2(a)). To evaluate whether PD-L1 expression on DCs could be related to viral infection, we stimulated DCs with live or UV-inactivated $\mathrm{A}(\mathrm{H} 1 \mathrm{~N} 1) \mathrm{pdm} 09$ virus; we did not detect any significant differences in PD-L1 expression induced by live or UV-inactivated virus on DCs populations (Figure 1(b)), although it was slightly decreased in cDCs treated with the inactivated virus. Next, we considered the possibility that the kinetics of PD-1 and PD-L1 expression on T cells could be divergent; therefore, we analyzed the expression of these molecules over 7 days after $\mathrm{A}(\mathrm{H} 1 \mathrm{~N} 1) \mathrm{pdm} 09$ stimulation; the highest expression of PD-L1 on both $\mathrm{CD} 4^{+}$ and $\mathrm{CD} 8^{+} \mathrm{T}$ cells was detected after $18 \mathrm{~h}$ and decreased over time $(P<0.001)$ (Figure 1(c)). In the case of PD-1, we only observed significant differences after 3 days of virus stimulation in $\mathrm{CD}^{+} \mathrm{T}$ cells and after 7 days in $\mathrm{CD} 8^{+} \mathrm{T}$ cells $(P<0.05)$ (Figure $1(\mathrm{c}))$. To elucidate whether PDL1 expression on DCs and T cells could be caused directly by interaction with the virus, we stimulated enriched DCs and HLA-DR ${ }^{+}$cell-depleted T cells with $\mathrm{A}(\mathrm{H} 1 \mathrm{N1}) \mathrm{pdm} 09$. We found that PD-L1 expression on DCs was induced after interaction with the virus and was dependent on de novo protein synthesis (Figures $1(\mathrm{f})$ and $1(\mathrm{~g})$ ); however, PD-L1 expression induced on $\mathrm{T}$ cells by $\mathrm{A}(\mathrm{H} 1 \mathrm{~N} 1) \mathrm{pdm} 09$ was dependent on the presence of APCs in the culture (Figure S2(b)), and on de novo protein synthesis (Figures $1(\mathrm{~d})$ and $1(\mathrm{e})$ ). When we stimulated PBMCs with A(H1N1)pdm09 virus for $2 \mathrm{~h}$, and then added cycloheximide for $16 \mathrm{~h}, \mathrm{PD}-\mathrm{L} 1$ expression on both $\mathrm{CD}^{+}{ }^{+}$and $\mathrm{CD}^{+}{ }^{+}$cells was inhibited. (Figures $1(\mathrm{~d})$ and $1(\mathrm{e})$ ). These results indicate that $\mathrm{A}(\mathrm{H} 1 \mathrm{N1}) \mathrm{pdm} 09$ can induce PD-L1 expression directly on human DCs and in the case of T cells by de novo protein synthesis, albeit dependent on the presence of APCs as an early event. PD-1 expression on DCs was absent, and in the case of $\mathrm{T}$ cells, it was induced by $\mathrm{A}(\mathrm{H} 1 \mathrm{N1}) \mathrm{pdm} 09$ later in time. 
TABLE 1: Demographic data from patients.

\begin{tabular}{lcc}
\hline Variable & Total patients $(n=25)$ & H1N1+ $(n=13)$ \\
\hline Gender & H1N1- $(n=12)$ & 5 \\
$\quad$ Female & 5 & 8 \\
$\quad$ Male & 7 & 34.4 \\
Age (years) & & 25.0 \\
$\quad$ Mean & 46.8 \\
$\quad$ Median & 48.5 & 78 \\
Max & 76 & 17 \\
Min & 18 & $7643.8 \pm 5122.75$ \\
Leukocyte count $\left(\right.$ cells $\left./ \mathrm{mm}^{3}\right)($ mean \pm SD) & $7095.0 \pm 4178.43$ & $1403.8 \pm 695.84$ \\
Lymphocyte count $\left(\right.$ cells $\left./ \mathrm{mm}^{3}\right)($ mean $\pm S D)$ & $1913.0 \pm 1243.49$ & \\
\hline
\end{tabular}

3.2. PD-L1 Signaling Impairs T Cell Response against Pandemic A(H1N1)pdm09 Virus. We analyzed if PD-L1 expression induced by $\mathrm{A}(\mathrm{H} 1 \mathrm{~N} 1) \mathrm{pdm} 09$ could impair the $\mathrm{T}$ cell response against the virus. We blocked PD-L1 signaling during virusinduced $\mathrm{T}$ cell activation and established that blocking PDL1 did not compromise $\mathrm{T}$ cell proliferation induced by the $\mathrm{A}(\mathrm{H} 1 \mathrm{N1})$ pdm09 virus (Figures 2(a)-2(c)). However, we did observe that blocking PD-L1 decreased the proportion of early apoptotic (Annexin $\mathrm{V}^{+} 7-\mathrm{AAD}^{-}$) $\mathrm{CD}^{+} \mathrm{T}$ cells, 7 days after exposure to the H1N1 virus (Figures 2(d) and 2(f), $P<0.05)$. CD4 ${ }^{+} \mathrm{T}$ cells did not show any significant differences in apoptosis after PD-L1 blocking (Figure 2(e)). We also determined that blocking PD-L1 increased PBMCs' production of IFN- $\gamma$, IL-10, and TNF. In order to evaluate if the virus caused this blocking effect, we stimulated the PBMCs with the recombinant hemagglutinin (HA) of the $\mathrm{A}(\mathrm{H} 1 \mathrm{~N} 1) \mathrm{pdm} 09$ virus and measured cytokine production. We observed lower levels of IFN- $\gamma$, IL-10, and TNF when the whole $\mathrm{A}(\mathrm{H} 1 \mathrm{N1}) \mathrm{pdm} 09$ virus was added, compared to HA stimulation. Moreover, when PD-L1 signaling was blocked, the cytokine levels induced by the virus were higher than those induced by the hemagglutinin. HA cytokine production was not affected by PD-L1 blockade, suggesting that this effect is $\mathrm{A}(\mathrm{H} 1 \mathrm{N1})$ pdm09 virus-dependent (Figures 3(a)-3(c), $P<0.05)$. To evaluate if IFN- $\gamma$, IL-10, and TNF were mainly expressed by $\mathrm{CD}^{+} \mathrm{T}$ cells, we co-cultured isolated memory $\mathrm{CD} 4^{+} \mathrm{T}$ cells with sorted $\mathrm{cDC}$ s with or without PD-L1 blocking, and found that cytokine production by $\mathrm{CD} 4^{+} \mathrm{T}$ cells was dependent on the presence of $\mathrm{cDC}$ and increased when PD-L1 was blocked (Figures 3(d)-3(f), $P<0.05$ ). Neither in bulk PBMCs nor in co-cultures of purified cells did we observe an effect of PD-L1 blocking on IL-4, IL-17A, or IL6 production (data not shown). In addition, we found that after 7 days of culture, enriched cDCs still expressed PD-L1 after stimulation with $\mathrm{A}(\mathrm{H} 1 \mathrm{N1}) \mathrm{pdm} 09$ virus, in contrast, high expression of PD-L1 was observed in memory $\mathrm{CD}^{+}{ }^{+} \mathrm{T}$ cells even in the absence of virus stimulation (Figure S3). Together, these results indicate that blocking PD-L1 on PBMCs had no effect on $\mathrm{T}$ cell proliferation but significantly decreased $\mathrm{CD}^{+} \mathrm{T}$ cell apoptosis and increased IFN- $\gamma$, IL-10, and TNF production by $\mathrm{CD} 4^{+} \mathrm{T}$ cells.
3.3. PD-L1 Expression Is Increased on Dendritic Cells and T Cells from PBMCs of Patients Infected with A(H1N1)pdm09 Virus. We evaluated PD-L1 expression in A(H1N1)pdm09 infection. We analyzed PD-L1 expression on $\mathrm{T}$ cells and DCs from cryopreserved PBMCs collected from patients during the 2009 influenza pandemic. Our study included 25 patients with influenza-like illness and $10 \mathrm{HCs}$, as shown in Table 1. Thirteen patients were RT-PCR positive for infection with the $\mathrm{A}(\mathrm{H} 1 \mathrm{~N} 1) \mathrm{pdm} 09$ virus ( $\mathrm{pH} 1 \mathrm{~N} 1+)$, and the rest were categorized as pH1N1-. The median age of the patients was 48.5 years for $\mathrm{H} 1 \mathrm{~N} 1-$ and 25 for H1N1+. Lymphopenia was present in most of the $\mathrm{pH} 1 \mathrm{~N} 1+$ patients $(1403.8 \pm 695.84$ cells $/ \mathrm{mm}^{3}$ ) and in half of the $\mathrm{pH} 1 \mathrm{N1}-$ patients $(1913.0 \pm$ 1243.49 cells $/ \mathrm{mm}^{3}$ ). We evaluated the frequencies and phenotype of DCs and T cells by flow cytometry; the gating strategy and representative plots are shown in Figure S4.

We found that $\mathrm{pH} 1 \mathrm{~N} 1+$ patients had a lower proportion of cDCs compared to the HCs (Figure 4(a), $P<0.05$ ). No differences in the pDCs proportions between both groups were detected (Figure 4(b)). However, PD-L1 expression was increased on the $\mathrm{CDCs}$ and $\mathrm{pDCs}$ of both groups of patients compared to that of the HCs (Figure 4(c) pH1N1+, $P<0.01$; pH1N1-, $P<0.001$, and Figure $4(\mathrm{~d}), P<0.05)$. CD $4^{+}$T cells proportion tended to decrease in both groups of patients compared to that of HCs (Figure 4(e)). The CD8 ${ }^{+} \mathrm{T}$ cell proportion was decreased in both groups of patients when compared to HCs (Figure 4(f), pH1N1+ $P<0.05$, pH1N1$P<0.001)$. Relative PD-L1 expression was increased on $\mathrm{CD} 4^{+} \mathrm{T}$ cells in both groups of patients compared to that in HCs (Figure 4(g), pH1N1+ $P<0.001$, pH1N1- $P<0.01$ ), while in $\mathrm{CD}^{+} \mathrm{T}$ cells, it was only increased in $\mathrm{pH} 1 \mathrm{N1} 1+$ patients (Figure $4(\mathrm{~h}), P<0.05$ ).

3.4. PD-L1 Expression on $\mathrm{CD}^{+} \mathrm{T}$ Cells Is Associated with a Lower $T$ Cell Proportion in Patients Infected with A(H1N1)pdm09 Virus. Finally, to establish if PD-L1 expression in PBMCs from patients could be associated with the $\mathrm{T}$ cell proportion during infection, we performed a series of correlations of DCs and T cell proportions and determined PD-L1 expression in pH1N1+ and pH1N1- subjects. We detected an inverse correlation between PD-L1 expression 


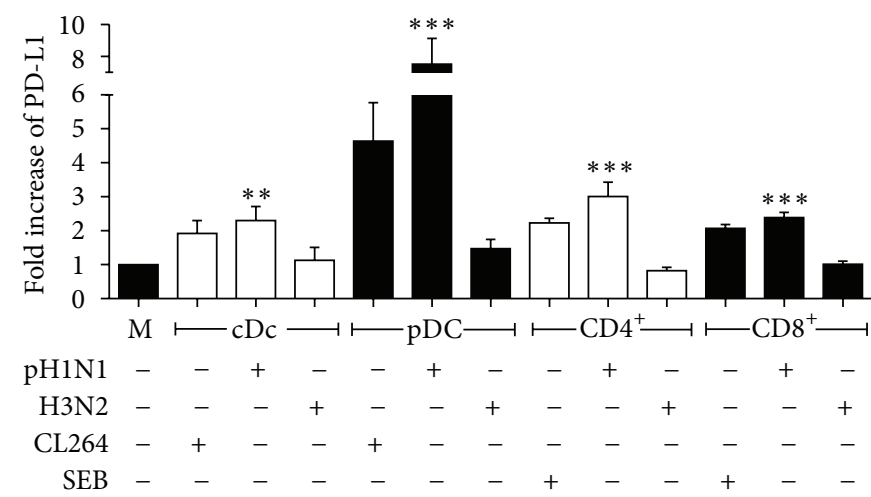

(a)

(c)
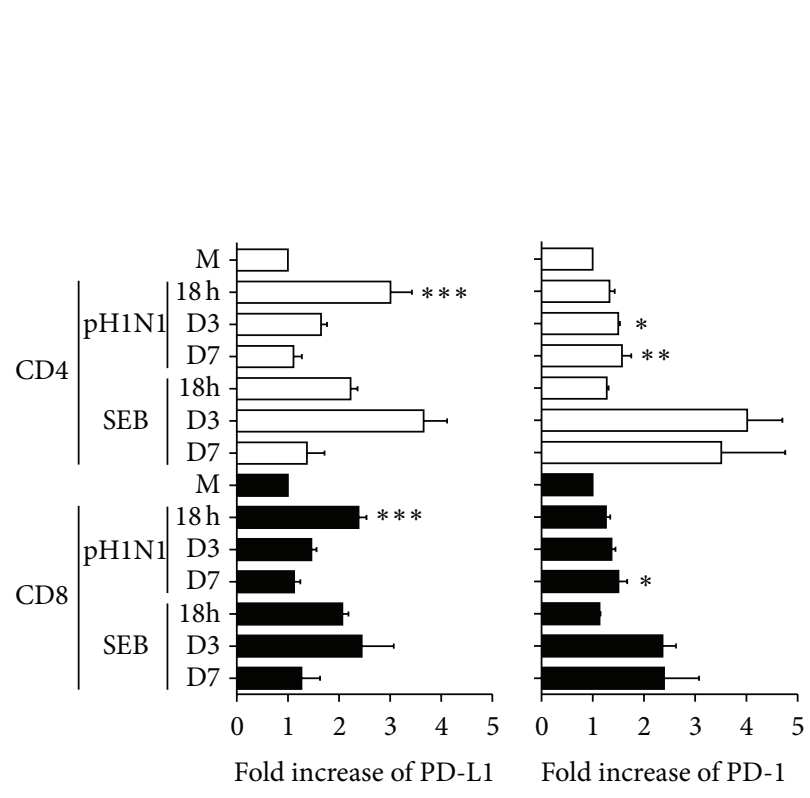

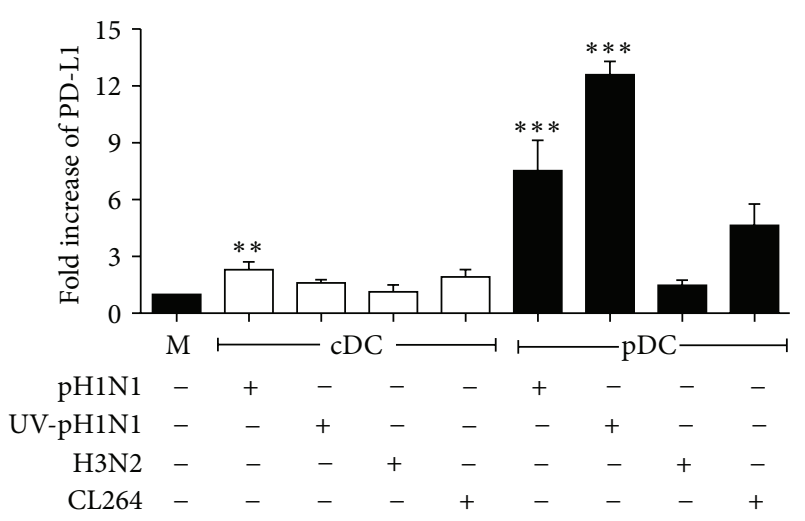

(b)

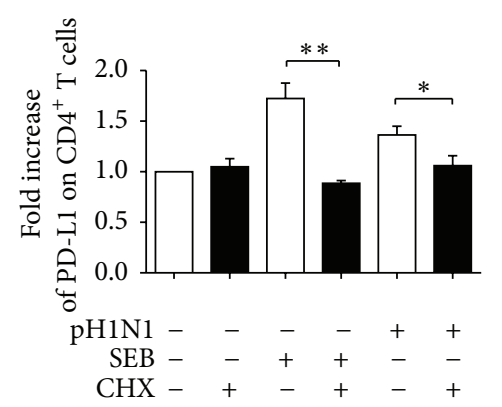

(d)

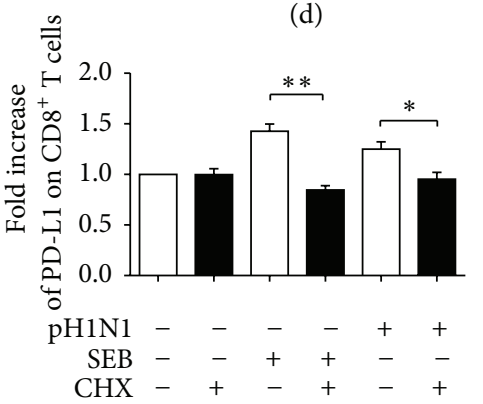

(e)

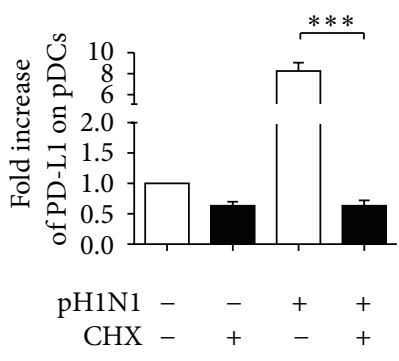

(f)

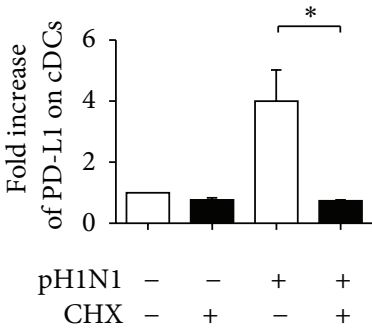

(g)

FIGURE 1: PD-L1 is expressed on human dendritic cells and T cells, whereas PD-1 is expressed only on T cells after exposure to A(H1N1)pdm09 virus. $\mathrm{PBMCs}$ were stimulated with $\mathrm{A}(\mathrm{H} 1 \mathrm{N1} 1) \mathrm{pdm} 09$ virus ( $\mathrm{pH} 1 \mathrm{~N} 1)$, seasonal influenza virus (H3N2), staphylococcal enterotoxin $\mathrm{B}$ (SEB), or synthetic TLR7 agonist (CL264); PD-L1 and PD-1 expression on DCs and T cells was analyzed by flow cytometry. (a) Fold increase in PD-L1 expression on conventional (cDCs) and plasmacytoid dendritic cells (pDCs), CD4 ${ }^{+}$, and $\mathrm{CD}^{+} \mathrm{T}$ cells after $18 \mathrm{~h}$ of stimulus. M: medium. (b) PBMCs were stimulated with live or UV-inactivated pH1N1 for $18 \mathrm{~h}$; virus and PD-L1 expression was measured on cDCs and pDCs. (c) Kinetics of PD-L1 and PD-1 expression on $\mathrm{CD}^{+}$and $\mathrm{CD}^{+} \mathrm{T}$ cells induced by $\mathrm{pH} 1 \mathrm{~N} 1$ or SEB. PBMCs were stimulated with pH1N1 for $2 \mathrm{~h}$, then cycloheximide $(\mathrm{CHX})$ was added for another $16 \mathrm{~h}$, and PD-L1 expression on $\mathrm{CD}^{+}(\mathrm{d}), \mathrm{CD}^{+} \mathrm{T}$ cells $(\mathrm{e})$, pDCs (f), and cDCs (g) was measured by flow cytometry. ( $n=5$ donors, error bars indicate standard error of the mean (SEM)). ${ }^{*} P<0.05,{ }^{* *} P<0.01$, and ${ }^{* * *} P<0.001$ by one way ANOVA test with Bonferroni posttest.

on $\mathrm{CD}^{+} \mathrm{T}$ cells and the proportion of both $\mathrm{T}$ cell subsets only in pH1N1+ patients (Figures 5(a) and 5(b), $P<0.05$ ); we did not find a significant correlation between PD-L1 expression and cell proportion in pH1N1- subjects or in DCs subsets (data not shown). As a whole, these results suggest that PD-L1 expression on T cells could be one of the factors mediating the decrease in the $\mathrm{T}$ cell proportion in $\mathrm{pHN} 1+$ patients.

\section{Discussion}

PD-L1 expression plays a critical role in chronic infections by impairing $\mathrm{T}$ cell function [5]. We report here that PD-L1 expression on DCs and T cells impairs T cell response to the influenza $\mathrm{A}(\mathrm{H} 1 \mathrm{N1}) \mathrm{pdm} 09$ virus in vitro. We also suggest that PD-L1 expression could have implications during the acute natural infection. 


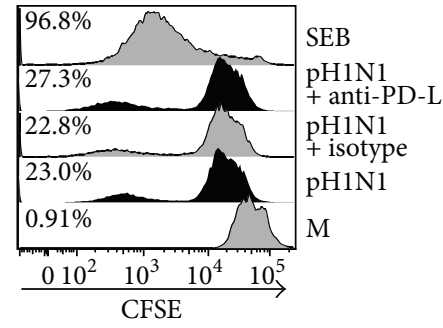

(a)

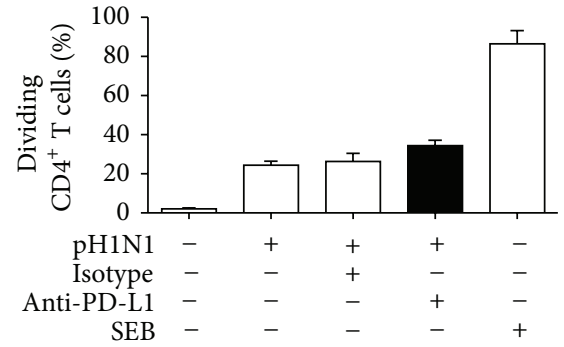

(b)

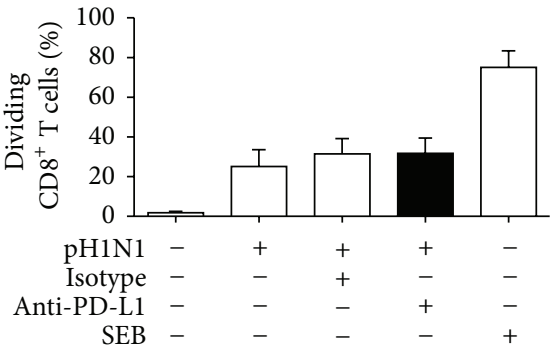

(c)
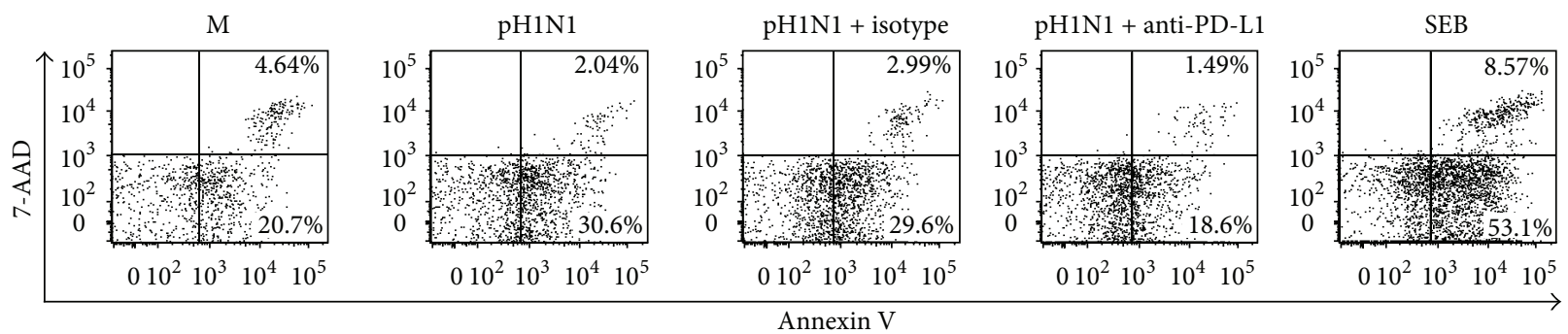

(d)

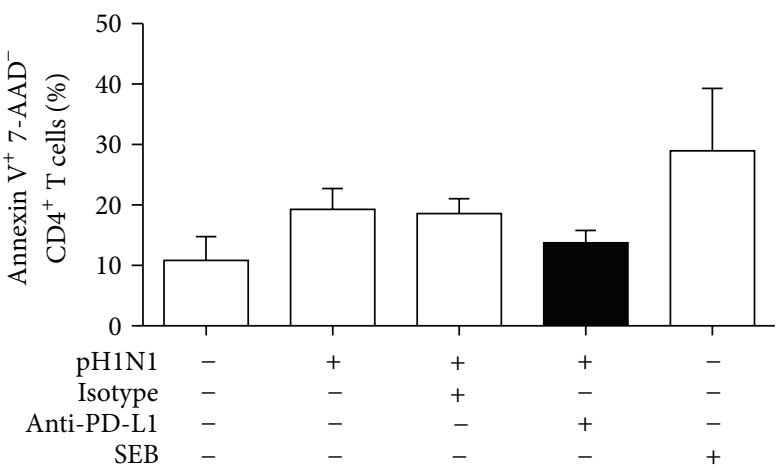

(e)

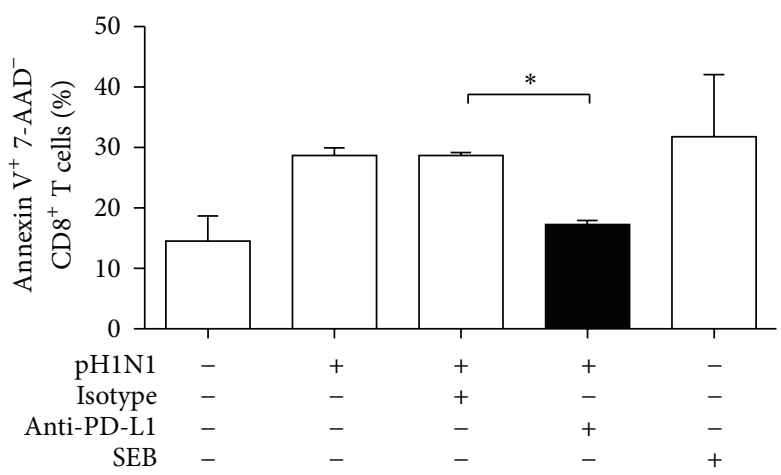

(f)

FIGURE 2: PD-L1 signaling blockade decreased $\mathrm{CD}^{+} \mathrm{T}$ cell death in vitro but did not have an effect on $\mathrm{T}$ cell proliferation in response to $\mathrm{A}(\mathrm{H} 1 \mathrm{N1}) \mathrm{pdm} 09$ virus. PBMCs from healthy individuals were stimulated with A(H1N1)pdm09 for $18 \mathrm{~h}$, washed, labeled with CFSE, and treated on days 0,3 , and 5 with a blocking anti-PD-L1 antibody or an isotype control. Cells were incubated for 7 days, and T cell proliferation and cell death were determined. SEB was used as a control. (a) Representative histograms of the CD4 $4^{+} \mathrm{T}$ cell CFSE dilution from one individual. $(\mathrm{b}, \mathrm{c}) \mathrm{T}$ cell proliferation expressed as the percentage of CFSE ${ }^{+}$dividing cells. (d) Representative plot of Annexin V and 7-AAD staining to

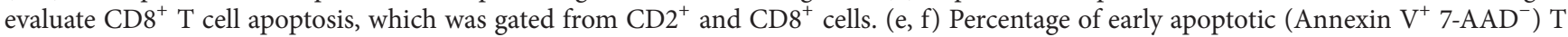
cells. $\left(n=7\right.$, error bars indicate SEM). ${ }^{*} P<0.05$ by Student's $t$-test.

$\mathrm{A}(\mathrm{H} 1 \mathrm{N1}) \mathrm{pdm} 09$ was able to induce PD-L1 expression on DCs in a similar manner to a TLR7 ligand. It has been documented that TLR7 and retinoid-induced gene receptor 1 (RIG-1) mediate the recognition of influenza virus in DCs [26]. Therefore, human peripheral DCs may recognize the $\mathrm{A}(\mathrm{H} 1 \mathrm{N1}) \mathrm{pdm} 09$ influenza virus through these receptors and subsequently express PD-L1 through a mechanism similar to that reported in influenza and other viral infections $[6,27]$. PD-1 and PD-L1 expression can be induced on T cells through TCR signaling $[2,28]$. We found that the PD-L1 expression induced by $\mathrm{A}(\mathrm{H} 1 \mathrm{~N} 1) \mathrm{pdm} 09$ on T cells was APC-dependent, and mostly hinged on de novo protein synthesis. Additionally, we show that $\mathrm{H} 3 \mathrm{~N} 2$ seasonal virus failed to induce PDL1 expression on either DCs or T cells; considering UVinactivated $\mathrm{pH} 1 \mathrm{~N} 1$ induced PD-L1, it is possible that the expression of PD-L1 observed is independent of the infection capacity of the viruses. According to these results, we conclude that in vitro, there is an important difference between the pandemic and the seasonal influenza viruses in terms of their ability to induce PD-L1 expression. Furthermore, we found that PD-1 up regulation was detected at late time points in $\mathrm{CD}^{+} \mathrm{T}$ and $\mathrm{CD} 8^{+} \mathrm{T}$ cells cultures, after contact with the $\mathrm{A}(\mathrm{H} 1 \mathrm{N1}) \mathrm{pdm} 09$ virus. This result is concordant with those observed in a recent mouse infection model, in which 


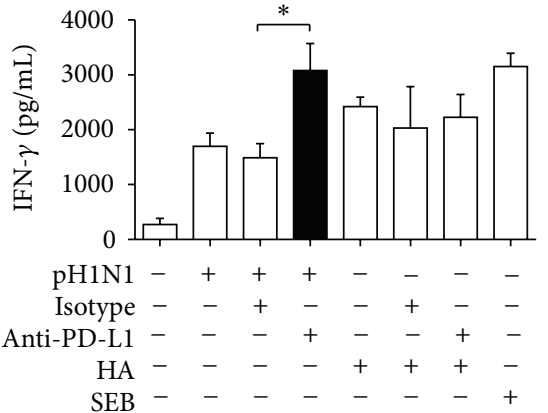

(a)

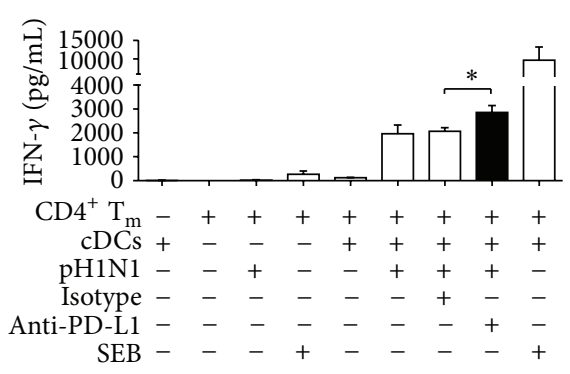

(d)

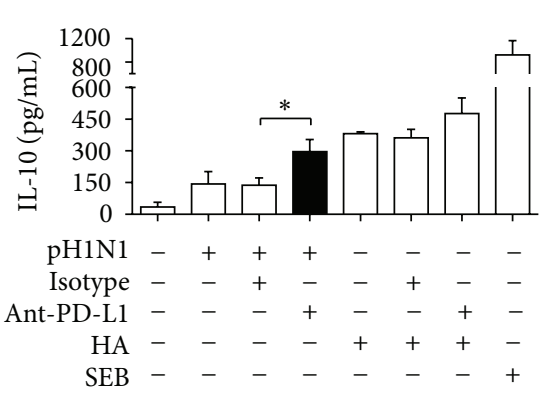

(b)

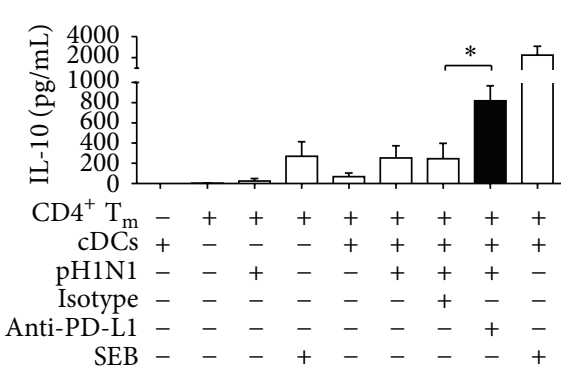

(e)

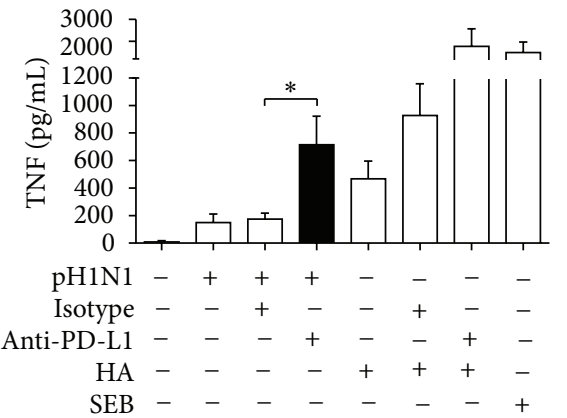

(c)

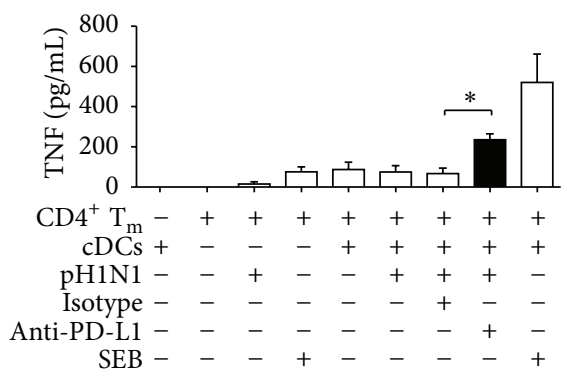

(f)

FIGURE 3: PD-L1 blocking increased in vitro IFN- $\gamma$, IL-10, and TNF production, predominantly by CD4 ${ }^{+}$T cells in response to A(H1N1)pdm09 virus. Cytokine levels in the supernatants (SN) of PBMCs cultured for 7 days as described in Figure 2 and PBMCs stimulated with hemagglutinin (HA) for 7 days were measured with a Th1/Th2/Th17 human cytometric bead array kit (CBA). The production of IFN- $\gamma$ (a), IL-10 (b), and TNF (c) by PBMCs is shown. Isolated memory CD4 ${ }^{+} \mathrm{T}$ cells $\left(\mathrm{T}_{\mathrm{m}}\right)$ and sorted cDCs were co-cultured with or without PD-L1 blocking for 7 days, and cytokine production in the SNs was measured; IFN- $\gamma$ (d), IL-10 (e), and TNF (f) levels are shown. Results are duplicates from 3 independent experiments and error bars indicate SEM. pH1N1: A(H1N1)pdm09 virus; SEB: staphylococcal enterotoxin B. ${ }^{*} P<0.05$ by Student's $t$-test.

cognate viral antigen was necessary and sufficient to induce PD-1 expression on $\mathrm{T}$ cells, and that PD-1 was expressed by lymphocytes in the lower airways during acute influenza infection in humans [10].

PD-L1 expression has been associated with T cell exhaustion and dysfunction during chronic viral infections and in some acute infections in both in vitro and in vivo models $[6,27]$. We have shown that similar $\mathrm{T}$ cell impairment mechanisms might also develop after interaction with A(H1N1)pdm09. Blocking PD-1/PD-L1 interaction enhanced the $\mathrm{T}$ cell response against $\mathrm{A}(\mathrm{H} 1 \mathrm{~N} 1) \mathrm{pdm} 09$ virus. Apoptosis was significantly decreased in $\mathrm{CD}^{+} \mathrm{T}$ cells, whereas cytokine production was increased; however, no impact was observed on $\mathrm{T}$ cell proliferation. One explanation for these results could be the late up regulation of $\mathrm{PD}-1$ expression on $\mathrm{T}$ cells. Therefore, $\mathrm{T}$ cell proliferation may not be affected by the PDL1 blockade because PD-1 expression was not apparent until day 3; however, the effects that we observed on $\mathrm{CD}^{+}{ }^{+} \mathrm{T}$ cell differentiation (cytokine production) when PD-L1 signaling was blocked, could be attributed to their expression of PD1 until day 3. In addition, PD-L1 expression is maintained over time (7 days) in $\mathrm{A}(\mathrm{H} 1 \mathrm{N1}) \mathrm{pdm} 09$ stimulated cDCs and is highly expressed on memory $\mathrm{CD}^{+} \mathrm{T}$ cells, indicating that these cells could be a source of PD-L1 during the late phase of T cell differentiation. Moreover, PD-1 is expressed on
$\mathrm{CD}^{+}$T cells 7 days after $\mathrm{A}(\mathrm{H} 1 \mathrm{~N} 1)$ pdm09 stimulation, which correlates with decreased $\mathrm{T}$ cell death. There are previous reports suggesting that after direct virus exposure, human $\mathrm{CD}^{+} \mathrm{T}$ cells are more susceptible to apoptosis than $\mathrm{CD} 4^{+}$ $\mathrm{T}$ cells [21]. In agreement with this finding, we observed that blocking PD-L1 after stimulation with A(H1N1)pdm09 could prevent $\mathrm{CD}^{+}$but not $\mathrm{CD} 4^{+} \mathrm{T}$ cell death.

Interestingly, we also observed that blocking PD-L1 caused an increase in the production of IL-10, IFN- $\gamma$, and TNF that may be associated with impairment of T cell differentiation induced by the virus, because when we stimulated cells with HA and blocked the PD-1/PD-L1 interaction, we did not observe any effects on cytokine production. The $\mathrm{A}(\mathrm{H} 1 \mathrm{~N} 1)$ pdm09 virus has also been reported to induce a decrease in cytokine levels in human DCs when compared with seasonal viruses in vitro [29]. Our study shows that PDL1 expression induced by $\mathrm{A}(\mathrm{H} 1 \mathrm{~N} 1)$ pdm09 could inhibit the production of both inflammatory and regulatory cytokines in human bulk PBMCs and in co-cultures of purified cDCs and memory $\mathrm{CD}^{+}{ }^{+} \mathrm{T}$ cells. It has been established that $\mathrm{T}$ cells from patients infected with $\mathrm{A}(\mathrm{H} 1 \mathrm{N1}) \mathrm{pdm} 09$ cannot differentiate into effector cells, do not respond to mitogens, and highly express CD95 (Fas), suggesting an apoptosis-related mechanism for the lymphopenia reported in A(H1N1)pdm09 infection [25]. Furthermore, these findings could contribute 


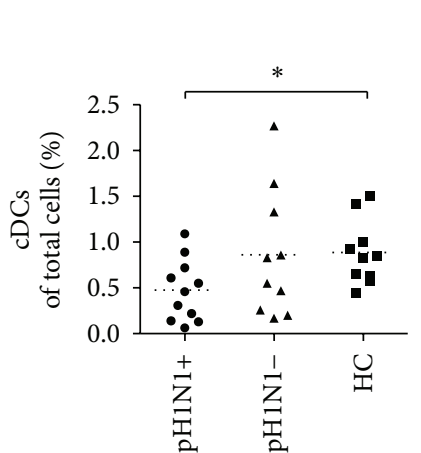

(a)

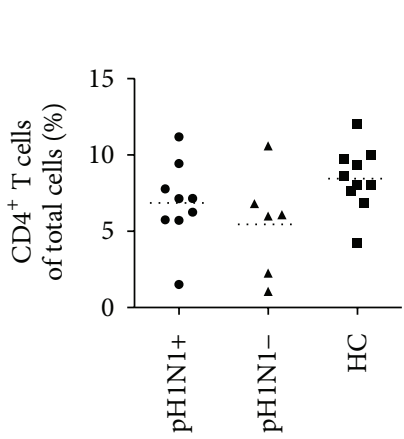

(e)

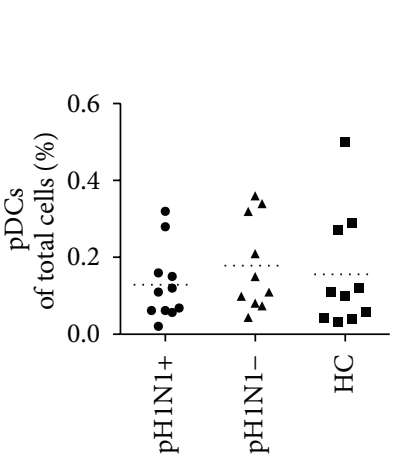

(b)

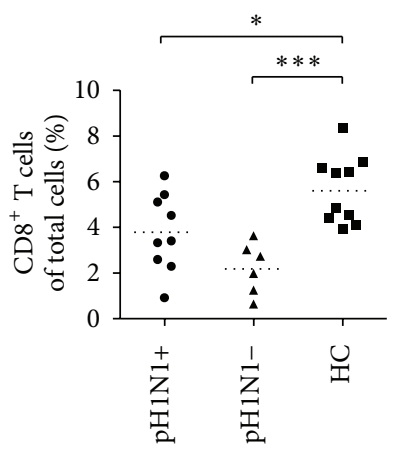

(f)

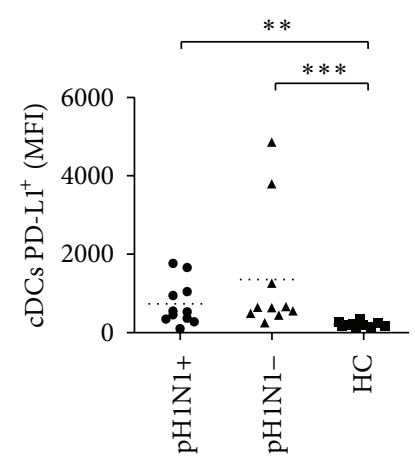

(c)

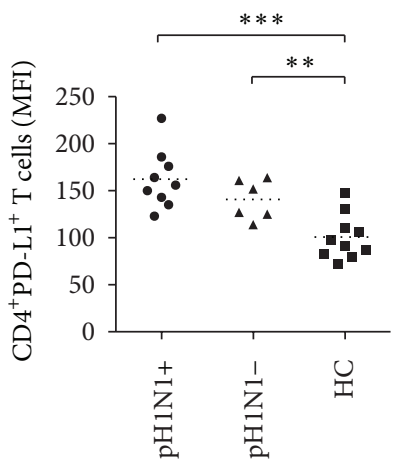

(g)

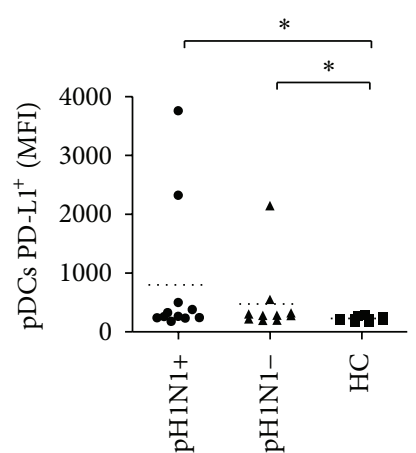

(d)

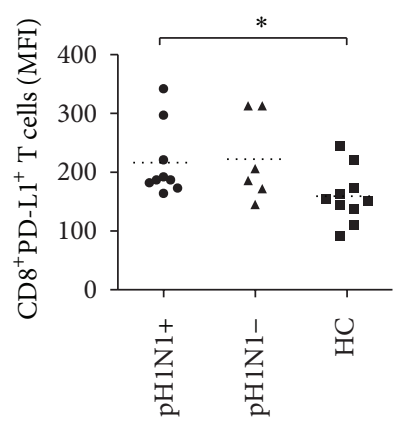

(h)

FIGURE 4: PD-L1 expression is increased on dendritic cells and T cells from PBMCs of patients with acute influenza infection. Cell proportions and surface PD-L1 expression on $\mathrm{cDCs}$ and $\mathrm{pDCs}(\mathrm{a}-\mathrm{d})$ and $\mathrm{CD}^{+}$and $\mathrm{CD} 8^{+} \mathrm{T}$ cells $(\mathrm{e}-\mathrm{h})$ from cryopreserved PBMCs from patients with confirmed infection with $\mathrm{A}(\mathrm{H} 1 \mathrm{~N} 1) \mathrm{pdm} 09$ virus ( $\mathrm{pH} 1 \mathrm{N1} 1+)$, patients with influenza-like illness but with a negative RT-PCR result for pandemic H1N1 influenza (pH1N1-), and healthy controls (HC, $n=10$; error bars indicate SEM) were analyzed by flow cytometry. MFI: mean fluorescence intensity; pH1N1: A(H1N1)pdm09 virus. ${ }^{*} P<0.05,{ }^{* *} P<0.01$, and ${ }^{* * *} P<0.001$ (Mann-Whitney test).

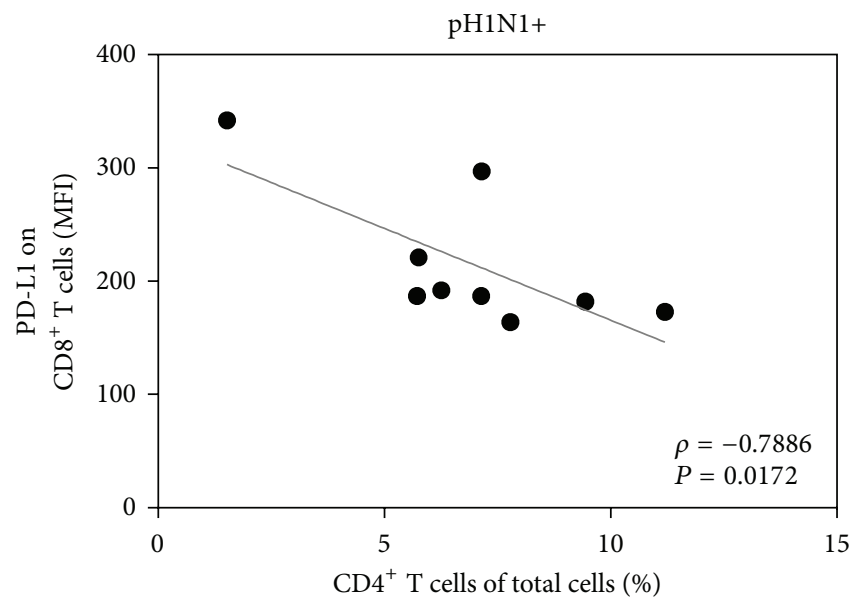

(a)

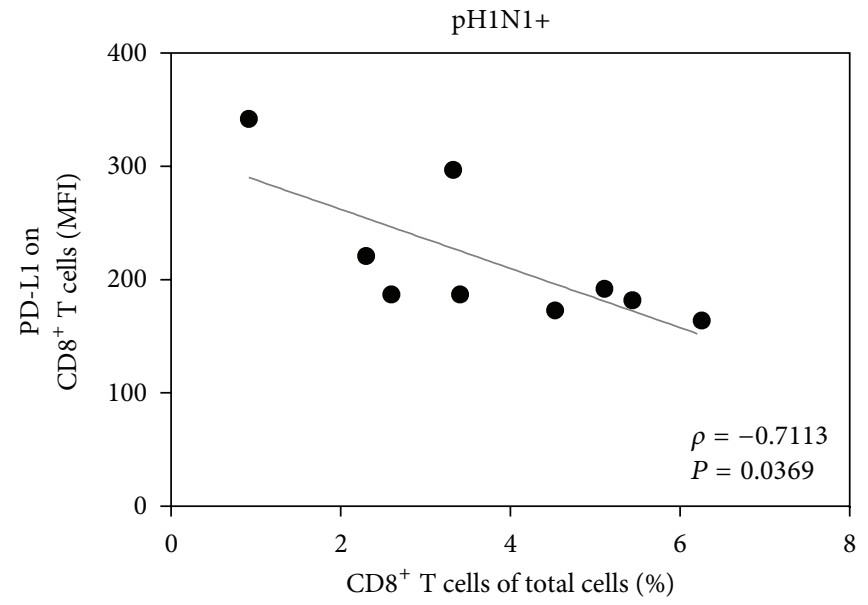

(b)

FIGURE 5: PD-L1 expression on $\mathrm{CD}^{+} \mathrm{T}$ cells is associated with a decreased $\mathrm{T}$ cell proportion in patients with acute $\mathrm{A}(\mathrm{H} 1 \mathrm{N1}) \mathrm{pdm} 09$ viral infection. Correlations between PD-L1 expression on the proportions of $\mathrm{CD}^{+}$and $\mathrm{CD}^{+} \mathrm{T}$ cells in PBMCs from pH1N1+ patients are shown. Correlations between PD-L1 expression on $\mathrm{CD}^{+} \mathrm{T}$ cells and the proportion of total CD4 ${ }^{+}$(a) and CD8 ${ }^{+}$(b) $\mathrm{T}$ cells in PBMCs in pH1N1+ patients are indicated. Spearman correlation $(\rho)$ and $P$ values are shown in each graph. MFI: mean fluorescence intensity; pH1N1: $\mathrm{A}(\mathrm{H} 1 \mathrm{~N} 1) \mathrm{pdm} 09$ virus. 
to understanding the regulation of cytokine expression and the control of the exacerbated immune response during infection, as has been previously reported [12].

We observed low frequency of $\mathrm{cDCs}$ in the blood of patients infected with $\mathrm{A}(\mathrm{H} 1 \mathrm{~N} 1)$ pdm09 during the first and second pandemic waves in Mexico City. It has been reported that in influenza-infected patients, DCs are recruited in the lung, suggesting that the low proportions that we observed may be caused by the redistribution of the DC population from the blood to the lung [30]. Moreover, we observed a decrease in the proportion of $\mathrm{CD}^{+} \mathrm{T}$ cells in influenzainfected patients; thus, $\mathrm{CD}^{+} \mathrm{T}$ cells may also have been redistributed to the lungs. However, we found an increase in PD-L1 expression in DCs and T cells of pH1N1+ patients; it is possible that $\mathrm{PD}-1 / \mathrm{PD}-\mathrm{L} 1$ signaling enhanced $\mathrm{CD} 8^{+} \mathrm{T}$ cell apoptosis as reflected in the decreased $\mathrm{T}$ cell proportion and as we showed in the in vitro assays results.

Our in vitro results showed that unlike the A(H1N1)pdm09 virus, the $\mathrm{H} 3 \mathrm{~N} 2$ virus did not induce $\mathrm{PD}-\mathrm{L} 1$ expression either in DCs or T cells; however, in addition to the seasonal H3N2 virus, seasonal H1N1 viruses were also circulating at that time in Mexico, so we cannot rule out that seasonal H1N1 virus could have also induced PD-L1 expression. Considering that our ex vivo results showed that PD-L1 up regulation may not be strain specific, and that in the natural infection additional immune mediators may contribute to PD-L1 up regulation, we do not discard the possibility that different types of influenza A virus could induce PD-L1 expression on DCs and T cells during acute infection.

PD-1 and PD-L1 have been recently reported to be expressed in the lungs of A(H1N1)pdm09 patients [10]. Since we did not analyze respiratory tissue samples, it was not possible to determine if the consequences of $\mathrm{PD}-\mathrm{L} 1$ expression on $\mathrm{T}$ cells and DCs that we observed in peripheral blood could reflect the localized response in lungs.

In $\mathrm{A}(\mathrm{H} 1 \mathrm{~N} 1) \mathrm{pdm} 09$ infected patients, $\mathrm{PD}-\mathrm{L} 1$ expression on $\mathrm{CD}^{+}{ }^{+} \mathrm{T}$ cells is inversely correlated with $\mathrm{CD} 4^{+}$and $\mathrm{CD} 8^{+}$ $\mathrm{T}$ cell proportions, but this correlation was only observed in pH1N1+ patients; this finding could be explained by the fact that the lymphopenia induced by $\mathrm{A}(\mathrm{H} 1 \mathrm{~N} 1) \mathrm{pdm} 09$ has been reported to be more severe and refractory than that associated with seasonal infection, which is modest during the first days and resolves earlier [31]. Since we detected PDL1 expression in both $\mathrm{pH} 1 \mathrm{~N} 1+$ and $\mathrm{pH} 1 \mathrm{N1}$ - patients, we consider that additional factors related to the immune response and inflammation triggered during the acute infection (such as interferons), could be involved in the correlation between PD-L1 expression on $\mathrm{CD}^{+} \mathrm{T}$ cells and the proportion of $\mathrm{T}$ cells observed only in pH1N1+ patients [32,33].

Our data suggest that viral infection may impair the induction of an efficient adaptive immune response in the early stages of infection by promoting PD-L1 expression on DCs and T cells; this could be a mechanism of immune evasion by the $\mathrm{A}(\mathrm{H} 1 \mathrm{~N} 1) \mathrm{pdm} 09$ virus, similar to that reported in chronic and acute viral infections [6,27,34-36]. Since the analyzed patients were recruited at the beginning of the pandemic outbreak in Mexico City, whether these observations are a particular characteristic of early pandemic outbreaks or can also be observed during seasonal outbreaks remains to be elucidated. Our findings suggest that PD-L1 expression could be a useful marker in the evaluation of the early $\mathrm{T}$ cell response against influenza infection and may be a possible target for intervention in patients with other acute viral respiratory infections.

\section{Conclusion}

The 2009 pandemic influenza $\mathrm{A}(\mathrm{H} 1 \mathrm{N1})$ virus is able to impair $\mathrm{T}$ cell responses through PD-L1 expression, suggesting that the virus could modulate host immune responses during infection by this mechanism.

$\begin{array}{ll}\text { Abbreviations } & \\ \text { PD-L1: } & \text { Programmed death ligand-1 } \\ \text { PD-1: } & \text { Programmed death-1 } \\ \text { cDC: } & \text { Conventional dendritic cell } \\ \text { pDC: } & \text { Plasmacytoid dendritic cell } \\ \text { A(H1N1)pdm09/pH1N1: } & \text { 2009 pandemic influenza } \\ & \text { A(H1N1) virus } \\ \text { HC: } & \text { Healthy control } \\ \text { PBMC: } & \text { Peripheral blood mononuclear } \\ & \text { cells } \\ \text { SEB: } & \text { Staphylococcal enterotoxin B } \\ \text { HA: } & \text { Hemagglutinin. }\end{array}$

\section{Acknowledgments}

The authors declare no competing financial interests. The authors acknowledge funding provided by the Mexican Social Security Institute (IMSS) through the Fondo de Investigación en Salud projects as follows: FIS/IMSS/PROT/703 and FIS/IMSS/PROT/G11/954, awarded to Constantino LópezMacías. Funding was also provided by the Instituto de Ciencia y Tecnología del Distrito Federal, Project no. PICDSI09248, awarded to Armando Isibasi. Nuriban Valero-Pacheco and Luz María Mora-Velandia obtained Ph.D. fellowships from the Mexican National Science and Technology Council (CONACYT) and from the IMSS. Nuriban Valero-Pacheco performed the experiments, analyzed the results, and wrote the paper, Lourdes Arriaga-Pizano and Eduardo FeratOsorio recruited the patients, Rodolfo Pastelin-Palacios analyzed the results, Luz María Mora-Velandia performed the experiments, Miguel Ángel Villasís-Keever performed the statistical design and analysis, Celia Alpuche-Aranda contributed with the influenza viruses, Luvia Enid SánchezTorres and Armando Isibasi analyzed the results and revised the paper, Laura Bonifaz designed the experiments, discussed the results, and wrote the paper, and Constantino LópezMacías planned the study, supervised the experiments, analyzed the results, and revised the paper.

\section{References}

[1] G. J. Freeman, A. J. Long, Y. Iwai et al., "Engagement of the PD-1 immunoinhibitory receptor by a novel B7 family member leads to negative regulation of lymphocyte activation," Journal of Experimental Medicine, vol. 192, no. 7, pp. 1027-1034, 2000. 
[2] J. A. Brown, D. M. Dorfman, F.-R. Ma et al., "Blockade of programmed death-1 ligands on dendritic cells enhances $\mathrm{T}$ cell activation and cytokine production," Journal of Immunology, vol. 170, no. 3, pp. 1257-1266, 2003.

[3] N. Patsoukis, J. Brown, V. Petkova, F. Liu, L. Li, and V. A. Boussiotis, "Selective effects of PD-1 on Akt and Ras pathways regulate molecular components of the cell cycle and inhibit $\mathrm{T}$ cell proliferation," Science Signaling, vol. 5, no. 230, article ra46, 2012.

[4] L. Carter, L. A. Fouser, J. Jussif et al., "PD-1:PD-L inhibitory pathway affects both $\mathrm{CD} 4^{+}$and $\mathrm{CD} 8^{+} \mathrm{T}$ cells and is overcome by IL-2," European Journal of Immunology, vol. 32, no. 3, pp. 634643, 2002.

[5] M. E. Keir, M. J. Butte, G. J. Freeman, and A. H. Sharpe, "PD1 and its ligands in tolerance and immunity," Annual Review of Immunology, vol. 26, pp. 677-704, 2008.

[6] M. Lafon, F. Mégret, S. G. Meuth et al., "Detrimental contribution of the immuno-inhibitor B7-H1 to rabies virus encephalitis," Journal of Immunology, vol. 180, no. 11, pp. 7506-7515, 2008.

[7] O. Talay, C.-H. Shen, L. Chen, and J. Chen, "B7-H1 (PD-L1) on $\mathrm{T}$ cells is required for T-cell-mediated conditioning of dendritic cell maturation," Proceedings of the National Academy of Sciences of the United States of America, vol. 106, no. 8, pp. 2741-2746, 2009.

[8] X. Huang, F. Venet, Y. L. Wang et al., "PD-1 expression by macrophages plays a pathologic role in altering microbial clearance and the innate inflammatory response to sepsis," Proceedings of the National Academy of Sciences of the United States of America, vol. 106, no. 15, pp. 6303-6308, 2009.

[9] Y. Zhang, J. Li, J. Lou et al., "Upregulation of programmed death-1 on T cells and programmed death ligand-1 on monocytes in septic shock patients," Critical Care, vol. 15, no. 1, article R70, 2011

[10] J. J. Erickson, P. Gilchuk, A. K. Hastings et al., "Viral acute lower respiratory infections impair $\mathrm{CD}^{+} \mathrm{T}$ cells through $\mathrm{PD}-1$," The Journal of Clinical Investigation, vol. 122, no. 8, pp. 2967-2982, 2012.

[11] D. Trabattoni, M. Saresella, M. Biasin et al., "B7-H1 is upregulated in HIV infection and is a novel surrogate marker of disease progression," Blood, vol. 101, no. 7, pp. 2514-2520, 2003.

[12] M. D. De Jong, C. P. Simmons, T. T. Thanh et al., "Fatal outcome of human influenza A (H5N1) is associated with high viral load and hypercytokinemia," Nature Medicine, vol. 12, no. 10, pp. 1203-1207, 2006.

[13] D. Kobasa, S. M. Jones, K. Shinya et al., "Aberrant innate immune response in lethal infection of macaques with the 1918 influenza virus," Nature, vol. 445, no. 7125, pp. 319-323, 2007.

[14] R. Almansa, A. Anton, P. Ramirez et al., "Direct association between pharyngeal viral secretion and host cytokine response in severe pandemic influenza," BMC Infectious Diseases, vol. 11, article 232, 2011.

[15] R. G. Douglas Jr., R. H. Alford, T. R. Cate, and R. B. Couch, "The leukocyte response during viral respiratory illness in man," Annals of Internal Medicine, vol. 64, no. 3, pp. 521-530, 1966.

[16] T. T. Hien, N. T. Liem, N. T. Dung et al., "Avian Influenza A (H5N1) in 10 Patients in Vietnam," The New England Journal of Medicine, vol. 350, no. 12, pp. 1179-1188, 2004.

[17] R. Perez-Padilla, D. De La Rosa-Zamboni, S. P. De Leon et al., "Pneumonia and respiratory failure from swine-origin influenza A (H1N1) in Mexico," The New England Journal of Medicine, vol. 361, no. 7, pp. 680-689, 2009.
[18] N. J. Roberts Jr. and J. E. Nichols, "Regulation of lymphocyte proliferation after influenza virus infection of human mononuclear leukocytes," Journal of Medical Virology, vol. 27, no. 3, pp. 179-187, 1989.

[19] V. S. Hinshaw, C. W. Olsen, N. Dybdahl-Sissoko, and D. Evans, "Apoptosis: a mechanism of cell killing by influenza A and B viruses," Journal of Virology, vol. 68, no. 6, pp. 3667-3673, 1994.

[20] T. Takizawa, S. Matsukawa, Y. Higuchi, S. Nakamura, Y. Nakanishi, and R. Fukuda, "Induction of programmed cell death (apoptosis) by influenza virus infection in tissue culture cells," Journal of General Virology, vol. 74, part 11, pp. 2347-2355, 1993.

[21] J. E. Nichols, J. A. Niles, and J. Roberts N.J., "Human lymphocyte apoptosis after exposure to influenza A virus," Journal of Virology, vol. 75, no. 13, pp. 5921-5929, 2001.

[22] B. D. Forrest, M. W. Pride, A. J. Dunning et al., "Correlation of cellular immune responses with protection against cultureconfirmed influenza virus in young children," Clinical and Vaccine Immunology, vol. 15, no. 7, pp. 1042-1053, 2008.

[23] A. J. McMichael, F. M. Gotch, G. R. Noble, and P. A. S. Beare, "Cytotoxic T-cell immunity to influenza," The New England Journal of Medicine, vol. 309, no. 1, pp. 13-17, 1983.

[24] T. M. Wilkinson, C. K. F. Li, C. S. C. Chui et al., "Preexisting influenza-specific $\mathrm{CD}^{+}{ }^{+} \mathrm{T}$ cells correlate with disease protection against influenza challenge in humans," Nature Medicine, vol. 18, no. 2, pp. 274-280, 2012.

[25] C. Agrati, C. Gioia, E. Lalle et al., "Association of profoundly impaired immune competence in H1N1v-infected patients with a severe or fatal clinical course," Journal of Infectious Diseases, vol. 202, no. 5, pp. 681-689, 2010.

[26] J. M. Lund, L. Alexopoulou, A. Sato et al., "Recognition of single-stranded RNA viruses by Toll-like receptor 7," Proceedings of the National Academy of Sciences of the United States of America, vol. 101, no. 15, pp. 5598-5603, 2004.

[27] S. Kirchberger, O. Majdic, P. Steinberger et al., "Human rhinoviruses inhibit the accessory function of dendritic cells by inducing sialoadhesin and B7-H1 expression," Journal of Immunology, vol. 175, no. 2, pp. 1145-1152, 2005.

[28] H. Nishimura, Y. Agata, A. Kawasaki et al., "Developmentally regulated expression of the PD-1 protein on the surface of double-negative (CD4-CD8-) thymocytes," International Immunology, vol. 8, no. 5, pp. 773-780, 1996.

[29] P. Österlund, J. Pirhonen, N. Ikonen et al., "Pandemic H1N1 2009 influenza a virus induces weak cytokine responses in human macrophages and dendritic cells and is highly sensitive to the antiviral actions of interferons," Journal of Virology, vol. 84, no. 3, pp. 1414-1422, 2010.

[30] M. A. Gill, K. Long, T. Kwon et al., "Differential recruitment of dendritic cells and monocytes to respiratory mucosal sites in children with influenza virus or respiratory syncytial virus infection," Journal of Infectious Diseases, vol. 198, no. 11, pp. 1667-1676, 2008.

[31] B. A. Cunha, F. M. Pherez, S. Strollo, U. Syed, and M. Laguerre, "Severe swine influenza A (H1N1) versus severe human seasonal influenza A (H3N2): clinical comparisons," Heart and Lung, vol. 40, no. 3, pp. 257-261, 2011.

[32] J. F. Bermejo-Martin, R. Ortiz de Lejarazu, T. Pumarola et al., "Th1 and Thl7 hypercytokinemia as early host response signature in severe pandemic influenza," Critical Care, vol. 13, no. 6, article R201, 2009.

[33] H.-H. Shen, J. Hou, W.-W. Chen et al., "Immunologic changes during pandemic (H1N1) 2009, China," Emerging Infectious Diseases, vol. 17, no. 6, pp. 1053-1055, 2011. 
[34] A. J. Zajac, J. N. Blattman, K. Murali-Krishna et al., "Viral immune evasion due to persistence of activated T cells without effector function," Journal of Experimental Medicine, vol. 188, no. 12, pp. 2205-2213, 1998.

[35] M. Mühlbauer, M. Fleck, C. Schütz et al., "PD-L1 is induced in hepatocytes by viral infection and by interferon- $\alpha$ and $-\gamma$ and mediates T cell apoptosis," Journal of Hepatology, vol. 45, no. 4, pp. 520-528, 2006.

[36] H. Xu, X. Wang, B. Pahar et al., "Increased B7-H1 expression on dendritic cells correlates with programmed death 1 expression on $\mathrm{T}$ cells in simian immunodeficiency virus-infected macaques and may contribute to $\mathrm{T}$ cell dysfunction and disease progression," Journal of Immunology, vol. 185, no. 12, pp. 73407348, 2010. 


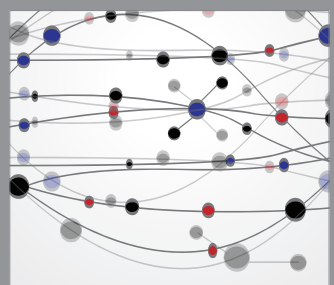

The Scientific World Journal
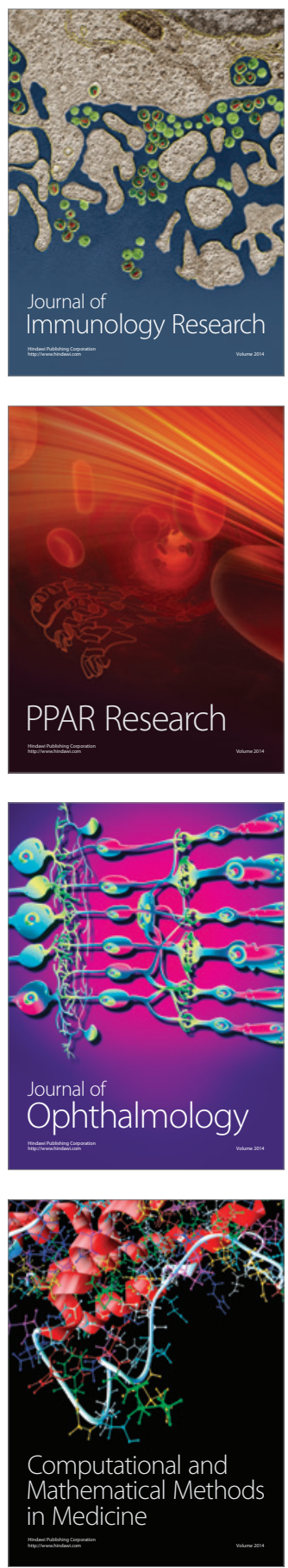

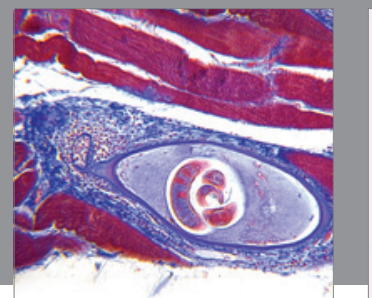

Gastroenterology

Research and Practice
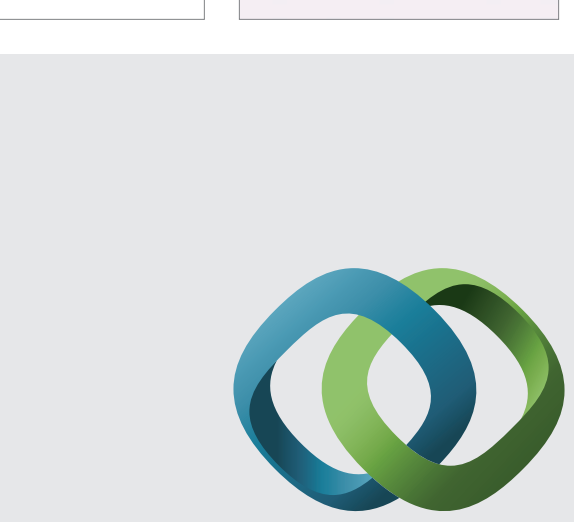

\section{Hindawi}

Submit your manuscripts at

http://www.hindawi.com
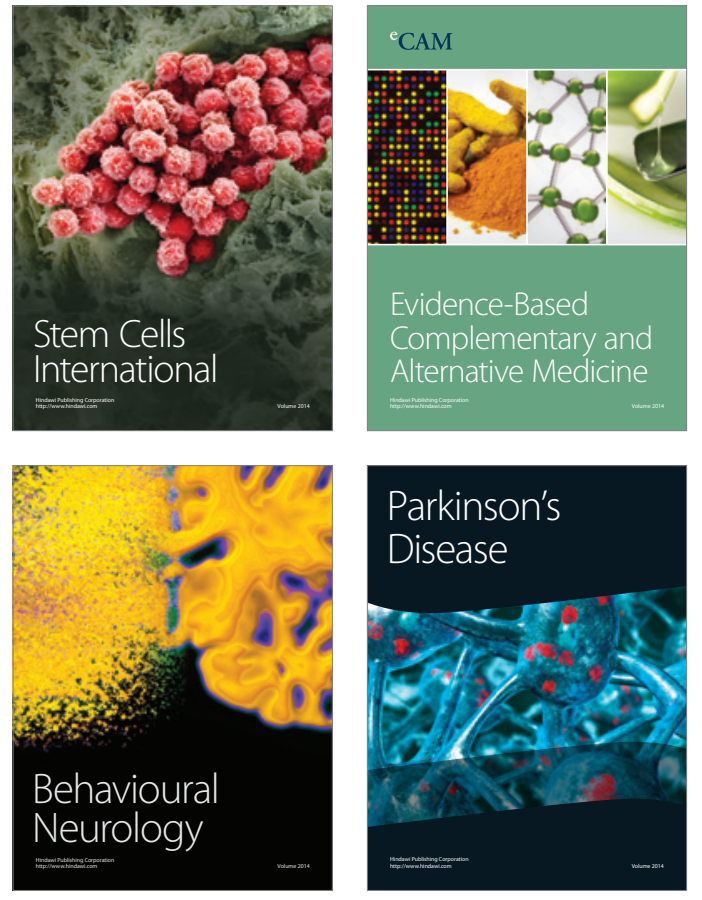
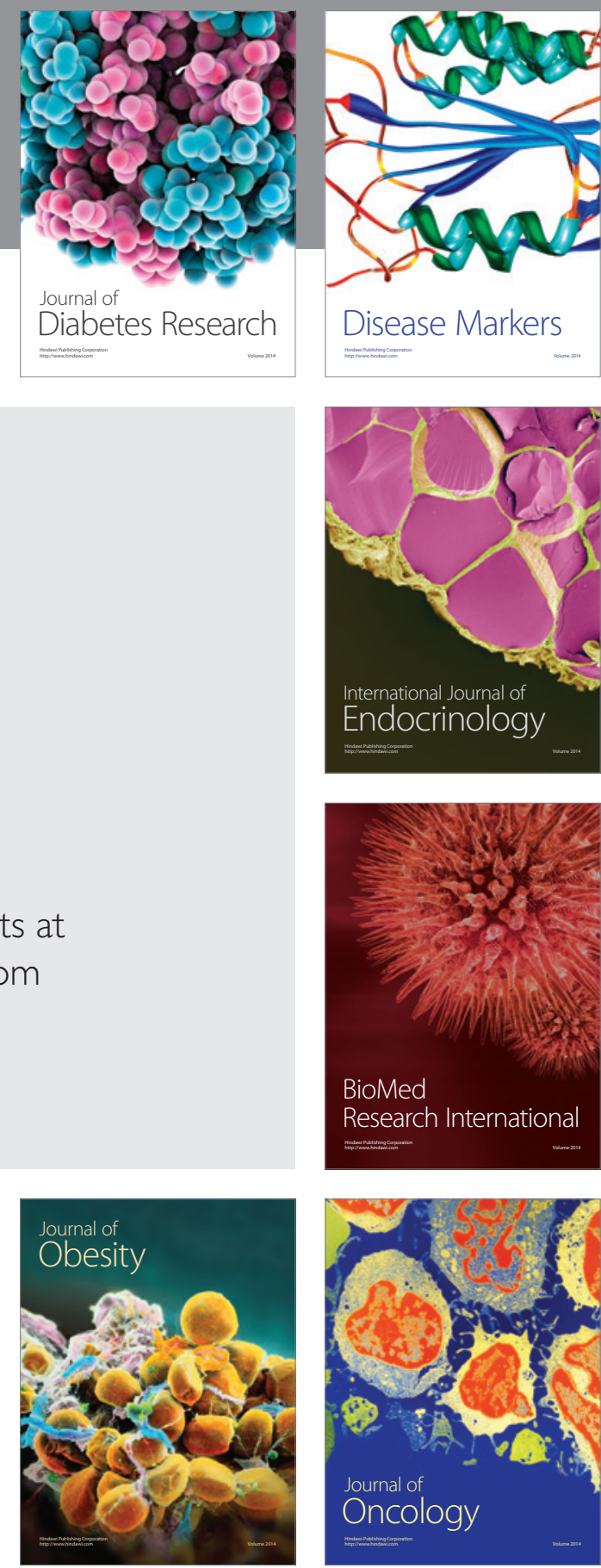

Disease Markers
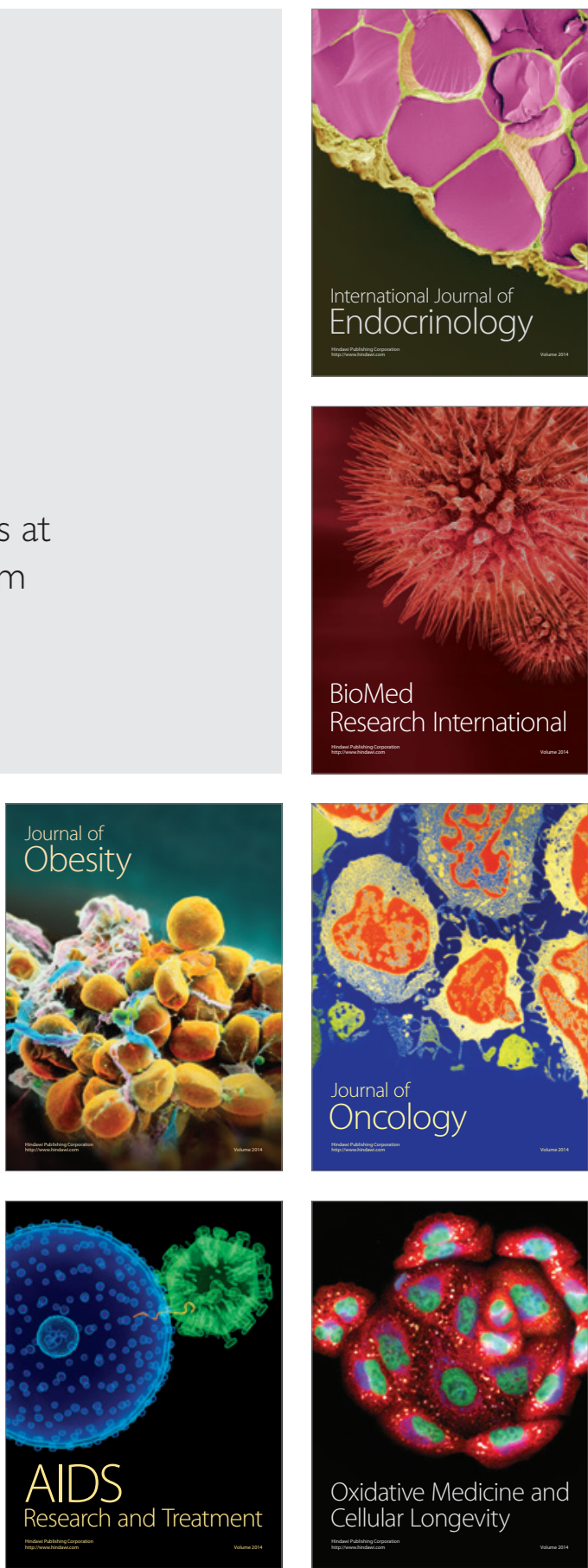